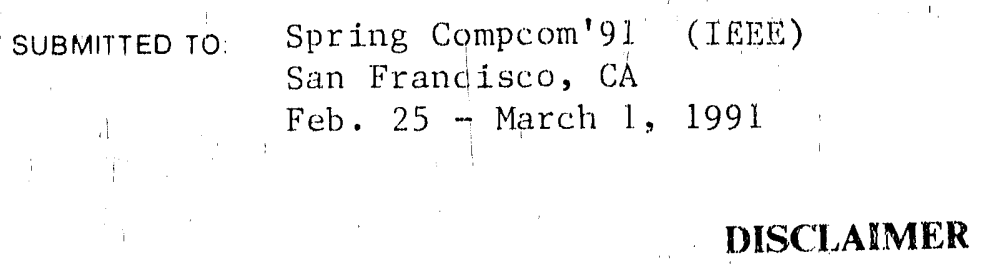
employees, makes any warranty, express or implied, or assumes any legal liability or responsibility for the accuracy, completeness, or usefulness of any information, apparatus, product, or process disclosed, or represents that its use would not infringe privately owned rights. Reference herein to any specific commercial product, process, or service by trade nawe, trademark, manufacturer, or otherwise foes not necessarily constitute or imply its endoryenvent, recommendation, or faysung by the United States Government or any agency thereof. The views and opinions of authors expressad herein do not necessarily state or reflect those of the United States Government or any agenc: thereof. 


\title{
OPPORTUNITIES FOR ACCELERATING COMMERCIAL DEVELOPMENT VIA EFFECTIVE PARTNERING
}

\author{
Ronald E. Barks \\ Industrial Applications Office \\ Los Alamos National Laboratory \\ Post Office Box 1663 \\ Los Alamos, NM 87545
}

In this age of intense economic competition, U.S. companies have available to them an enormous pool of resources in the federal laboratory system which they can leverage to their competitive advantage. Since 1980 , by a series of laws and executive orders, the resources in the federal laboratories have been made increasingly available to private industry via technology transfer efforts in support of National Competitiveness Objectives. These objectives are as follows:

1. The creation of quality jobs in America.

2. Maintenance of our standard of living.

3. Reduction of our balance of payments.

To this end, the 500 Federal laboratories from 14 agencies have a combined budget of about $\$ 20$ billion per year plus and are staffed with over 100,000 scientists and engineers.

How does one access these resources? The first step is to know what you need and to identify where it might be found in the Federal system. Daunting? Not really. The simplest wav to begin is by reviewing the topical literature from professional societies dealing in the technology of i.terest. Conference agendas, professional society journals, and newsletters are all fixcellent sources of leads on the type of research being done, where it is being performed, and who is doing it. You can locate technoiogy in the Fec eral system by contacling any of the following:

1. The National Technical Information Service (NTIS) run by the Department of Commerce.
2. The Office of Science and Technology Information (OSTI) run by the Department of Energy.

3. The Federal Laboratory Consortium representing all of the labs in the system.

Unless you are contacting a specific individual at one of the labs, you should ask to speak to someone in the technology transfer office in that facility.

At Los Alamos, with the help of our corporate partners, we have established an approach to their requests which has significantly increased the probabiiity for success. Rather than have a company contact us and ask, "What do we have," which does not work very well, we suggest that they write us and define their interest in any one or combination of the following ways: The business opportunities being sought; the technology(ics) reeded; problems ro be solved. By providing more depth in the interest(s) being pursued, we have the opportunity to provide approaches that might not have been considered at all by the requesting company. A real value-added service. On receipt of the company's letter, we will send copies to those scientists and engineers most likely to be able to contribute their expertise. They in turn may identify someone uniquely qualified to respond. If we have what is sought at Los Alamos, the company representatives will be invited to visit. We will arrange a meeting with all those scientists and engineers who have responded. The company personnel will be expected to give a presentation about their company in general, then about the 
specific reason for the visit. Those Los Alamos personnel on the agenda will be invited to the company's presentation. This permits them to tailor their subsequent presentations to the exact interests of the company. The result has often been a successful visit resulting in a technology transfer effort between the company and Los Alamos National Laboratory. Technology at government laboratories is generally developed in response to the programmatic need of a particular agency. As such, it is generally not directly applicable to the specific interests of a company. Should that technology be transferred to a company, it will generally have to be adapted to the company's product/process interests during an additional period of development. From my experience in product development for consumer industries, this could take two to three years or more. Yet at Los Alamos we have seen three of our licensed technologies taken to market in ten months or less from the signing of a license. These technologies represented a non-contact device to measure superconductivity in materials, a ferrate based process to remove trans-uranic elements from waste streams for environmental cleanup, and a high performance parallel interface tester for high speed computers. Such opportunitics to acceleratc development with federal technology are real, resulting in considerable development, savings, shorter times to market, and more rapid return of profits. These technologies can frequently be obtained by licensing, on an exclusive or nonexclusive basis, thereby affording protection to the patents or copyrights on which they are based. Why not assist your companics in taking advantage of opportunities in the federal laboratory system.

My staff and I will assist you in making contacts within this system. 

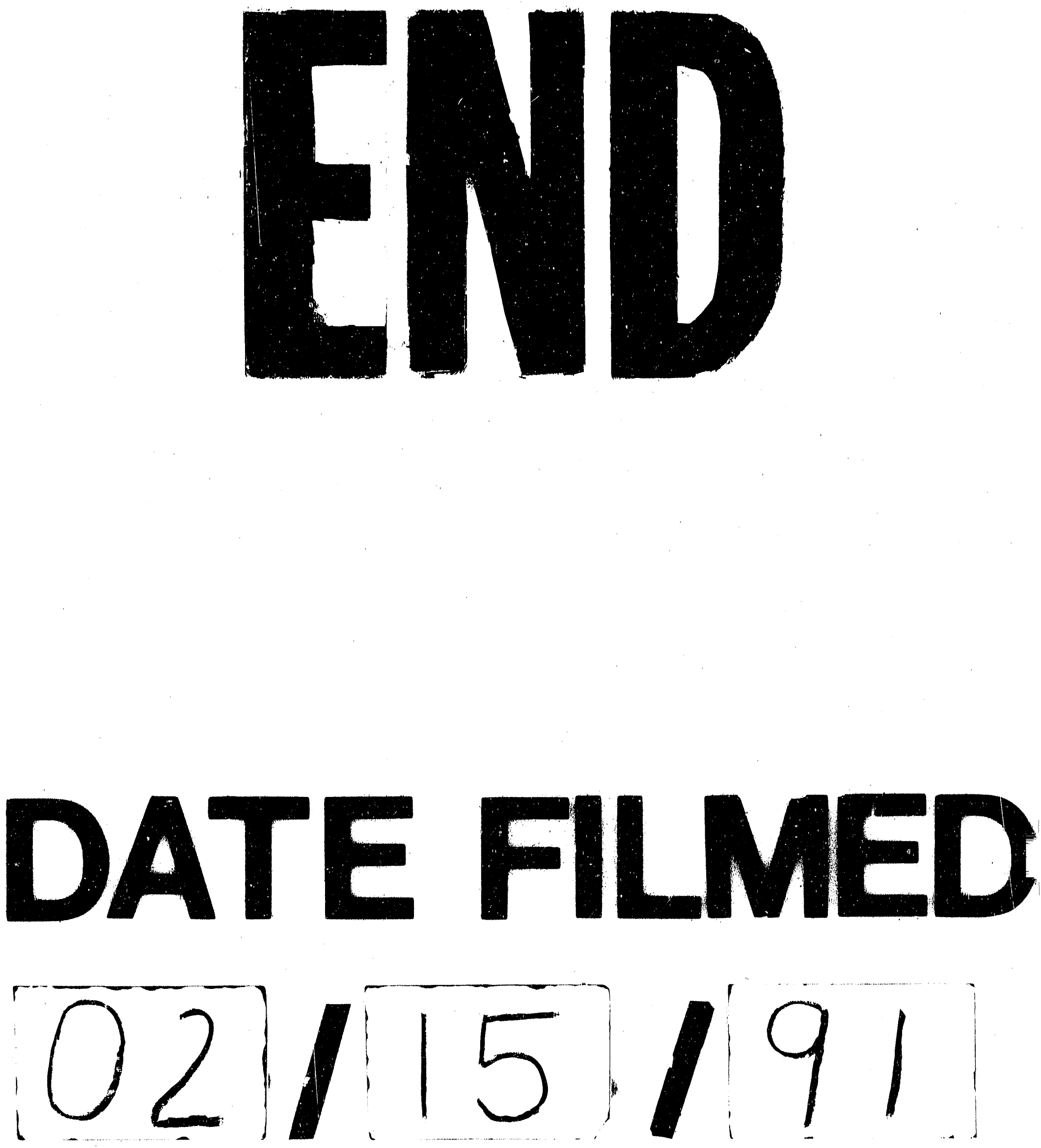


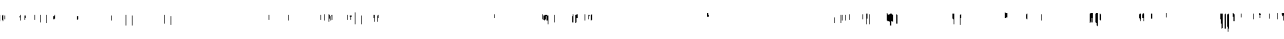

